\title{
Pengaruh Lama Modifikasi Heat-Moisture Treatment (HMT) Terhadap Sifat Fungsional dan Sifat Amilografi Pati Talas Banten (Xanthosoma undipes K. Koch)
}

\section{Effect of Heat-Moisture Treatment (HMT) Duration to Functional Properties and the Amylograph Properties of Banten Taro Starch (Xanthosoma undipes K. Koch)}

Fetriyuna $^{1}$, Marsetio ${ }^{1}$, Roofi Lintang Pratiwi ${ }^{2}$

Departemen Teknologi Industri Pangan Fakultas Teknologi Industri Pertanian Universitas Padjadjaran 1Dosen Fakultas Teknologi Industri Pertanian Departemen Teknologi Industri Pangan Universitas Padjadjaran

2Mahasiswa Fakultas Teknologi Industri Pertanian Departemen Teknologi Industri Pangan Universitas Padjadjaran

\begin{tabular}{l} 
A R T I C L E IN F O \\
\hline Article history \\
Received: 13 Juni 2016 \\
Accepted: 22 Juli 2016 \\
Available online: Februari 2017 \\
\hline Keywords : \\
Banten taro \\
native starch \\
HMT modification
\end{tabular}

Kata kunci :

Talas banten

pati alami

modifikasiHMT

\begin{abstract}
A B STRACT
Banten taro (Xanthosoma undipes $K$. Koch), a non rice starchy food, is a potential local commodities from the province of Banten. Starch of Taro tuber content approximately $15.21 \%(w b)$. Native starchhas severalshortcomings, namely forming a hard paste, toosticky properties, notresistanttoacid treatment, anda low viscosity. That limitation need to overcome by aphysicalmodificationof heat-moisture treatment (HMT) torectifythese shortcomings. These modifications improved the resilience of starch to heat and mechanical treatment, and improving gelatinization temperature and stability of starch paste. The aim of this study was to determine the effect of duration of HMT modification to functional properties and the amylograph properties of taro starch. The research methods was regression with 5 treatments and 3 replications. The treatments consistof duration of HMT modification of 4 hours, 8 hours, 12 hours, 16 hoursand20hours. The results showed that Banten taro starch that modified by HMT has increased the value of water absorption capacity and decrease of the swelling volume. This research also showed a tendency to increase freeze-thaw stability, solubility, the initial temperature of gelatinization, peak viscosity, hold viscosity, final viscosity and setback viscosity and a tendency to decrease whiteness and breakdown viscosity.
\end{abstract}

\section{A B S T R A K}

Talas banten (Xanthosoma undipes K. Koch) merupakan bahan pangan mengandung pati non beras yang merupakan potensi komoditas lokal dari Kabupaten Pandeglang, Provinsi Banten. Umbi talas banten memiliki kadar pati sebesar $15.21 \%$ (bb). Pati alami atau pati yang belum termodifikasi (native starch)mempunyai beberapa kekurangan yaitu pasta yang terbentuk keras, sifat yang terlalu lengket, tidak tahan dengan perlakuan asam, dan kekentalan rendah sehingga membutuhkan modifikasi fisik heat-moisture treatment (HMT) untuk memperbaiki kekurangan tersebut. Modifikasi ini dapat meningkatkan ketahanan pati terhadap panas dan perlakuan mekanis serta meningkatkan suhu gelatinisasi dan stabilitas pasta pati. Tujuan dari penelitian ini adalah untuk mengetahui pengaruh lama modifikasi HMT terhadap sifat fungsional dan sifat amilografi pati talas banten. Metode penelitian yaitu Regresi dengan 5 perlakuan dan 3 ulangan. Perlakuan terdiri dari lama modifikasi heat-moisture treatment 4 jam, 8 jam, 12 jam, 16 jam dan 20 jam. Hasil penelitian menunjukkan bahwa pati Talas Banten termodifikasi heat-moisture treatment mengalami peningkatan nilai kapasitas penyerapan air, penurunan nilai swelling volume, kecenderungan peningkatan freeze-thaw stability, kelarutan, suhu awal gelatinisasi, viskositas puncak, viskositas pasta panas, viskositas pasta dingin dan viskositas setback serta kecenderungan penurunan derajat putih dan viskositas breakdown. 


\section{Pendahuluan}

Talas Beneng (Xanthosoma undipes K. Koch) merupakan potensi komoditas lokal dari Provinsi Banten, Kabupaten Pandeglang karena pertumbuhannya yang mudah dan cepat. Pemanfaatan umbi talas Banten sejauh ini diolah menjadi keripik dan tepung yang diolah lebih lanjut menjadi makanan lainnya. Pemanfaatan yang masih terbatas namun pertumbuhan talas Banten yang mudah dan cepat menjadikan talas Banten berpotensi untuk dimanfaatkan dalan industri pangan secara luas.

Salah satu pemanfaatan yang dapat dilakukan adalah menjadi pati talas Banten. Umbi talas secara umum mempunyai kadar pati yang cukup tinggi dalam tepung talas yaitu sebesar 74.34\% (Setyowati dkk, 2007 dikutip Wahyuni, 2010) dengan kadar amilosa $21.44 \%$ dan amilopektin 78.56\% (Hartati dan Prana, 2003 dikutip Wahyuni, 2010). Umbi talas Beneng (Xanthosoma undipes $K$. Koch) sendiri memiliki kadar pati sebesar $15.21 \%$ (BBP2TP, 2015).

Pati alami atau pati yang belum termodifikasi (native starch) mempunyai beberapa kekurangan yaitu diantaranya tidak tahan terhadap perlakuan panas dan mekanis sehingga dibutuhkan modifikasi secara fisik dengan menggunakan metode Heat-Moisture Treatment (HMT) untuk memperbaiki kekurangan tersebut.

Penggunaan pati termodifikasi HMT cukup luas dalam industri pangan. Pati sagu termodifikasi HMT dapat dimanfaatkan salah satunya sebagai pengenyal dalam pembuatan bakso daging sapi (Felicia, 2010). Pati sagu termodifikasi HMT dapat dimanfaatkan juga dalam pembuatan bihun instan (Ramadhan, 2009).

\section{Metode Penelitian \\ Bahan dan Alat}

Bahan utama pada penelitian ini adalah talas Banten berusia 8 bulan yang diambil dari daerah Pandeglang, Banten. Bahan pendukung yang digunakan adalah akuades, alumunium foil, $\mathrm{BaSO}_{4}$ dan $\mathrm{NaCl}$.

Peralatan yang digunakan dalam pembuatan pati dan proses modifikasi pati adalah pisau, baskom, blender, kain saring, sendok, talenan, neraca analitik, kain saring, oven, grinder, sentrifugasi, tabung sentrifugasi dan ayakan.

Peralatan yang digunakan untuk analisis pati alami dan pati termodifikasi adalah tabung sentrifugasi, spatula, beaker glass, vortex, sentrifugasi, gelas ukur, waterbath, cawan alumunium, desikator, hotplate, thermometer raksa, refrigerator, freezer, botol semprot, botol penyimpanan, dan Rapid Visco Analyzer.

\section{Metode Penelitian}

Metode penelitian yang digunakan adalah metode eksperimental dengan analisis deskriptif (explanatory research) dan dilanjutkan dengan uji regresi dan korelasi menggunakan beberapa model yang menjelaskan hubungan antara variabel bebas dan variabel terikat. Variabel bebas (Xi) adalah lama modifikasi HMT dan variabel terikat (Y) adalah variabel yang diamati yaitu sifat fungsional meliputi, swelling volume, solubility, kapasitas penyerapan air, freeze thaw stability, kadar air, derajat putih dan sifat amilografi meliputi suhu awal gelatinisasi, viskositas puncak atau peak viscosity (PV), viskositas pasta panas atau trough viscosity (TV), perubahan viskositas selama pemanasan atau breakdown, viskositas pasta dingin atau final viscosity (FV), perubahan viskositas selama pendinginan atau setback.

Penelitian terdiri dari 5 perlakuan lama modifikasi HMT sebanyak 3 kali ulangan pada masing-masing perlakuan. Modifikasi pati talas banten dilakukan dengan suhu modifikasi $110^{\circ} \mathrm{C}$. Penelitian dilakukan dengan 5 perlakuan lama modifikasi HMT yaitu 4 jam, 8 jam, 12 jam, 16 jam dan 20 jam.

Percobaan dilakukan dengan tahapan sebagai berikut:

1) Pembuatan Pati Talas Banten Alami

Tahapan pembuatan pati talas banten alami dapat diuraikan sebagai berikut:

a. Sortasi

Pemisahan atau sortasi umbi talas banten yang berusia 8 bulan.

\section{b. Pengupasan}

Kulit umbi talas dikupas menggunakan pisau sekaligus membuang kotoran-kotoran yang menempel pada umbi seperti tanah dan tunas kecil yang tumbuh pada sekeliling umbi.

\section{c. Pemotongan dan Perendaman}

Pemotongan umbi talas banten hingga berukuran kecil. Umbi talas berukuran kecil tersebut kemudian direndam selama 120 menit dalam larutan $\mathrm{NaCl} 10 \%$. Perendaman bertujuan untuk mengeluarkan getah yang terdapat pada umbi talas.

d. Pencucian dan Penirisan air rendaman.

Pencucian dilakukan dengan membuang dan meniriskan air rendaman, kemudian umbi talas dicuci menggunakan air dan ditiriskan hingga getah hilang seluruhnya.

\section{e. Penghancuran}

Proses penghancuran menggunakan alat bantu blender dengan penambahan air untuk memudahkan penghancuran. Perbandingan Air: Talas adalah 2:1.

\section{f. Penyaringan dan pengendapan}

Penyaringan dilakukan menggunakan kain saring bersih di atas wadah yang akan digunakan untuk mengendapkan pati. Filtrat hasil penyaringan kemudian diendapkan selama semalam atau \pm 15 jam untuk memisahkan pati.

\section{g. Sentrifugasi}

Hasil pengendapan kemudian disentrifugasi untuk memisahkan pati dari zat non pati yang masih ikut mengendap. Sentrifugasi dilakukan dengan kecepatan 3000 rpm selama 15 menit. 
h. Pemisahan

Air dan zat non pati yang telah terpisah dari pati pada tabung sentrifugasi kemudian dipisahkan dengan cara dituang dan diambil menggunakan spatula kecil.

\section{i. Pengeringan}

Pengeringan bertujuan untuk mengurangi kadar air yang terdapat pada pati dan dilakukan pada suhu $50^{\circ} \mathrm{C}$ selama 24 jam.

\section{j. Penggilingan}

Pati yang telah dikeringkan selanjutnya digiling untuk memperkecil ukuran dan memudahkan proses pengayakan sehingga didapatkan pati dengan ukuran yang seragam. Proses penggilingan dilakukan dengan menggunakan grinder.

\section{k. Pengayakan}

Pati yang telah digiling kemudian diayak dengan menggunakan ayakan 100 mesh untuk mendapatkan ukuran partikel lolos 100 mesh.

\section{2) Modifikasi Heat-Moisture Treatment}

a. Pengaturan Kadar Air

Pengaturan kadar air dilakukan dengan penambahan akuades hingga mencapai kadar air $27 \% \pm 1$ dengan cara penyemprotan dan pengadukan secara manual bertujuan untuk penyeragaman kadar air pada proses Heat-Moisture Treatment (HMT). Jumlah akuades yang ditambahkan dihitung menggunakan prinsip kesetimbangan massa. Menurut Saputra (2012), rumus kesetimbangan massa yang dapat digunakan adalah sebagai berikut:

$$
\left(100 \%-\mathrm{KA}_{1}\right) \times \mathrm{BP}_{1}=\left(100 \%-\mathrm{KA}_{2}\right) \times \mathrm{BP}_{2}
$$

\section{Keterangan:}

$\mathrm{KA}_{1}=$ Kadar air kondisi awal (\%bb)

$\mathrm{KA}_{2}=$ Kadar air pati yang diinginkan (\%bb)

$\mathrm{BP}_{1}=$ Bobot pati pada kondisi awal

$\mathrm{BP}_{2}=$ Bobot pati setelah mencapai $\mathrm{KA}_{2}$

b. Penyeragaman Kadar Air dalam Refrigerator

Pati dibungkus dalam alumunium foil kemudian ditempatkan dalam loyang. Pati didinginkan dalam refrigerator pada suhu $4-5^{\circ} \mathrm{C}$ selama 24 jam untuk penyeragaman kadar air.

\section{c. Pemanasan}

Pati dikemas dengan alumunium foil tertutup rapat bertujuan untuk menjaga kadar air $27 \% \pm 1$. Pemanasan dilakukan pada suhu $110^{\circ} \mathrm{C}$ selama waktu yang telah ditetapkan sesuai dengan perlakuan untuk proses modifikasi Heat-Moisture Treatment (HMT). Pemanasan dilakukan dengan menggunakan oven cabinet.

\section{d. Pengeringan}

Pati yang telah diberi perlakuan pemanasan selanjutnya dibuka untuk dikeringkan. Pengeringan bertujuan untuk mengurangi kadar air yang terdapat pada pati sampai kadar air sebesar $12 \% \pm 2$ dan dilakukan pada suhu $50^{\circ} \mathrm{C}$ selama 4 jam.

\section{e. Penggilingan}

Pati yang telah dikeringkan selanjutnya digiling untuk memperkecil ukuran dan memudahkan proses pengayakan sehingga didapatkan pati dengan ukuran yang seragam. Proses penggilingan dilakukan dengan menggunakan grinder.

f. Pengayakan

Pati yang telah digiling kemudian diayak dengan menggunakan ayakan 100 mesh untuk mendapatkan ukuran partikel lolos 100 mesh.

\section{Kriteria Pengamatan}

Karakteristik yang diamati pada pati talas termodifikasi secara HMT adalah:

1. Sifat Fungsional terdiri dari:
a. Swelling volume dan Solubility (Collado and Corke, 1999)
b. Kapasitas penyerapan air secara gravimetri (Kadan et al., 2003)
c. Derajat putih (Soekarto, 1990)
d. Freeze thaw stability (Wattanachant et al., 2002)

2. Sifat Amilografi menggunakan alat Rapid Visco Analyzer (RVA) (Modifikasi Collado et al., 2001) terdiri dari:
a. Suhu awal gelatinisasi
b. Viskositas puncak
c. Viskositas pasta panas
d. Perubahan viskositas selama pemanasan (breakdown)
e. Viskositas pasta dingin
f. Perubahan viskositas selama pendinginan (setback)

\section{Hasil dan Pembahasan \\ Kapasitas Penyerapan Air}

Kurva hubungan antara lama modifikasi HMT dengan nilai kapasitas penyerapan air pati talas banten termodifikasi HMT mengikuti model regresi kuadratik dapat dilihat pada Gambar 1.

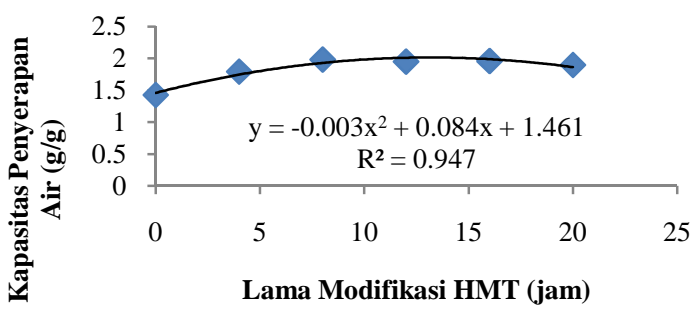

Gambar 1. Kurva Hubungan Lama Modifikasi HMT dengan Kapasitas Penyerapan

\section{Air Pati Talas Banten Termodifikasi HMT.}

Perlakuan modifikasi HMT dapat meningkatkan nilai kapasitas penyerapan air dari pati talas banten. 
Adebowale (2005) menyatakan bahwa perlakuan heatmoisture treatment dapat meningkatkan kapasitas pengikatan air pati sorgum merah karena adanya peningkatan kecenderungan sifat hidrofilik pada pati seiring dengan pertambahan tingkat kelembaban pati. Peningkatan ini disebabkan karena bagian amorphous mengalami sedikit pengembangan sehingga beberapa ikatan hidrogen antara bagian amorphous dan bagian kristalin akan putus untuk kemudian berikatan dengan hidrogen dari air

\section{Swelling Volume}

Kurva hubungan antara lama modifikasi HMT dengan nilai swelling volume pati talas banten termodifikasi HMT mengikuti model regresi kuadratik dapat dilihat pada Gambar 2.

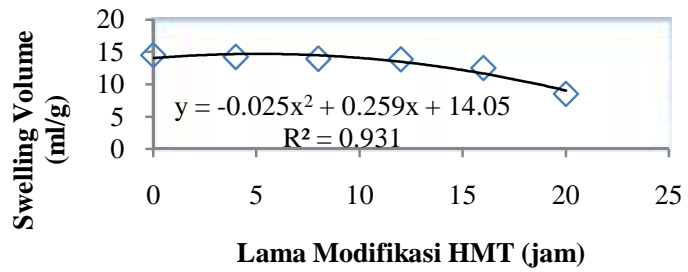

Gambar 2. Kurva Hubungan Lama Modifikasi HMT dengan Swelling Volume Pati Talas Banten Termodifikasi HMT

Perlakuan modifikasi HMT dapat menurunkan nilai swelling volume dari pati talas banten. Owolabi, Afolabi dan Adebowale (2010) menyatakan bahwa penurunan nilai swelling volume pati mungkin disebabkan oleh adanya perubahan dalam susunan kristalit pati dan atau adanya interaksi antar komponen pati pada daerah amorf granula selama modifikasi HMT. Telah dilaporkan terjadi penurunan nilai swelling power dari pati jagung termodifikasi HMT bila dibandingkan dengan pati jagung alami. Ahmad (2009) menyatakan bahwa perlakuan modifikasi HMT menyebabkan molekul granula pati tersusun menjadi lebih rapat sehingga kemampuan granula membengkak (swelling volume) menjadi terbatas atau mengalami penurunan.

\section{Kelarutan}

Kurva hubungan antara lama modifikasi HMT dengan nilai kelarutan pati talas banten termodifikasi HMT dapat dilihat pada Gambar 3.

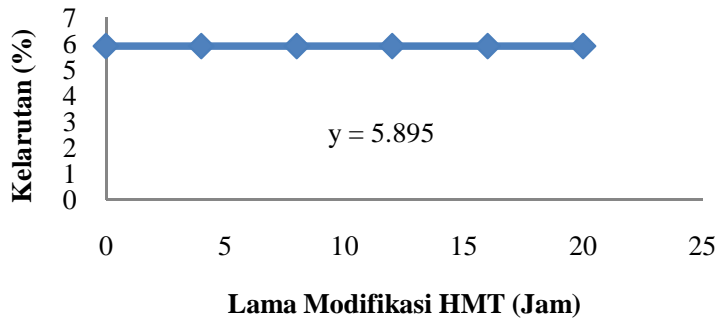

Gambar 3. Kurva Hubungan Lama Modifikasi HMT dengan Kelarutan Pati Talas Banten Termodifikasi HMT
Kelarutan pati terjadi akibat adanya molekul amilosa yang keluar dari granula (leaching amilosa) selama proses pemanasan dengan air berlebih. Keluarnya amilosa ini menandakan adanya transisi di dalam granula pati dari teratur menjadi tidak teratur ketika pati dipanaskan dengan air berlebih (Tester dan Morrison, 1990 dalam Zavarese dan Dias, 2011)

Berdasarkan hasil pengujian, nilai kelarutan pati talas banten alami adalah $6.65 \%$ sedangkan nilai kelarutan pati talas banten termodifikasi HMT adalah $6.70 \%$ hingga $18.20 \%$. Hal ini menunjukkan adanya kecenderungan peningkatan nilai kelarutan dari pati talas banten setelah mengalami modifikasi HMT meskipun perubahan yang terjadi tidak terlalu jauh sehingga dianggap tidak berbeda nyata dengan pati talas banten alami.

\section{Derajat Putih}

Kurva hubungan antara lama modifikasi HMT dengan nilai derajat putih pati talas banten termodifikasi HMT dapat dilihat pada Gambar 4.

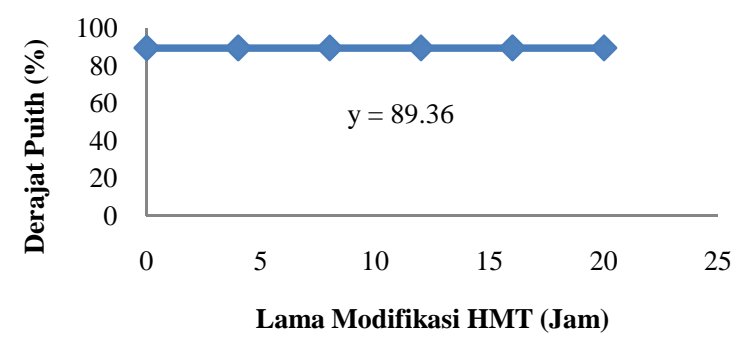

Gambar 4. Kurva Hubungan Lama Modifikasi HMT dengan Derajat Putih Pati Talas Banten Termodifikasi HMT

Berdasarkan pada hasil pengujian nilai derajat putih pati talas banten alami adalah $89.89 \%$, sedangkan nilai derajat putih pada pati talas banten termodifikasi adalah $80.19 \%$ hingga $81.45 \%$. Derajat putih pati talas banten termodifikasi HMT mengalami sedikit perubahan menjadi agak kecoklatan bila dibandingkan dengan pati talas banten alami. Namun, perubahan derajat putih pada pati talas banten termodifikasi HMT cenderung kecil antar perlakuan lama modifikasi

Perubahan nilai derajat putih terjadi karena proses pemanasan dan pengeringan pada pati selama modifikasi. Darmajana (2010) menyatakan bahwa umumnya bahan pangan yang mengalami proses pengeringan akan mengalami perubahan warna menjadi coklat. Perubahan warna yang terjadi disebabkan oleh reaksi pencoklatan non enzimatis pada pati.

\section{Freeze-Thaw Stability}

Kurva hubungan antara lama modifikasi HMT dengan nilai freeze-thaw stabilitypati talas banten termodifikasi HMT dapat dilihat pada Gambar 5. 


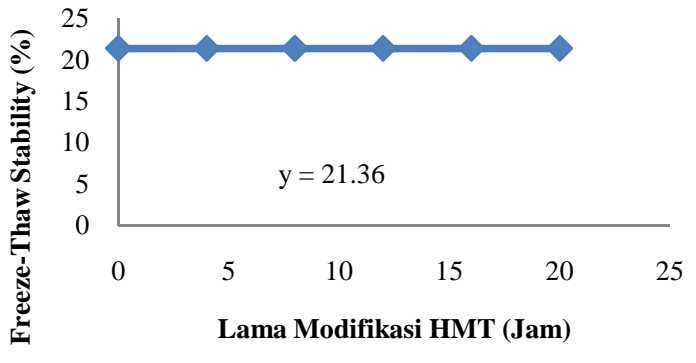

Gambar 5. Kurva Hubungan Lama Modifikasi HMT dengan Freeze-Thaw Stability Pati Talas Banten Termodifikasi HMT

Freeze-thaw stability dinyatakan dalam \% sineresis dapat diartikan sebagai persentase jumlah air yang terpisah setelah pasta diberi perlakuan penyimpanan pada satu siklus $-15^{\circ} \mathrm{C}$ (Sunarti dkk, 2007). Berdasarkan pada hasil pengujian, nilai freeze-thaw stability pati talas banten alami adalah $19.37 \%$ sedangkan freeze-thaw stability pati talas banten termodifikasi HMT adalah 29.04 $\%$ hingga $43.58 \%$. Hasil ini menunjukkan adanya kecenderungan peningkatan nilai freeze-thaw stability pati talas banten termodifikasi HMT dibandingan dengan pati talas banten alami.

Kecenderungan peningkatan nilai freeze-thaw stability menunjukkan pati lebih mudah mengalami sineresis. Menurut Syamsir (2012), swelling volume yang menurun akibat HMT meningkatkan peluang terjadinya agregasi amilosa dalam matriks gel yang cukup intensif.

\section{Sifat Amilografi}

Sifat amilografi berkaitan dengan pengukuran viskositas pati dengan konsentrasi tertentu selama pemanasan dan pengadukan. (Singh dkk, 2006). Kriteria yang dapat diamati adalah Suhu Awal Gelatinisasi, Viskositas Puncak, Viskositas Pasta Panas, Viskositas Breakdown, Viskositas Pasta Dingin dan Viskositas Setback.

Kurva amilografi pati talas banten termodifikasi HMT dapat dilihat pada Gambar 6.

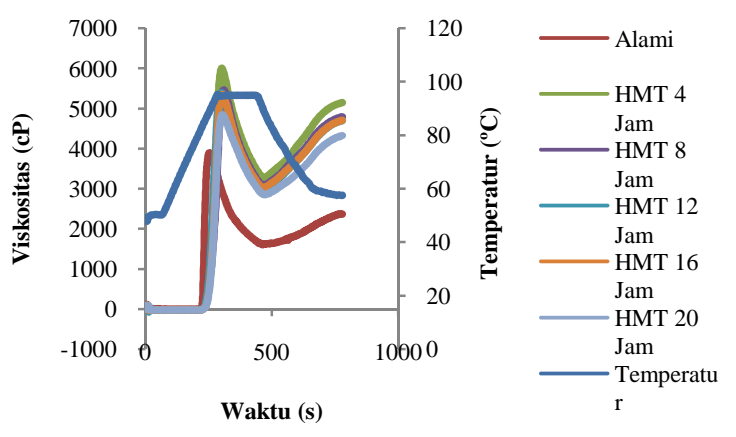

Gambar 6. Kurva Amilografi Pati Talas Banten Termodifikasi HMT
Berdasarkan pada gambar kurva amilografi, pati talas banten termodifikasi HMT memiliki profil gelatinisasi tipe A dilihat dari tingginya nilai viskositas puncak dan viskositas breakdown.

\section{- Suhu Awal Gelatinisasi}

Suhu awal gelatinisasi atau pasting temperature (PT) adalah suhu pada saat mulai terbentuknya viskositas dan menandakan pati mulai menyerap air (Takahashi dkk, 2005).

Berdasarkan pada hasil analisis suhu awal gelatinisasi pati talas banten alami adalah $81.95^{\circ} \mathrm{C}$ sedangkan suhu awal gelatinisasi pati talas banten termodifikasi HMT adalah $82.77{ }^{\circ} \mathrm{C}$ hingga $83.76^{\circ} \mathrm{C}$. Hal ini menunjukkan bahwa perlakuan modifikasi HMT dapat meningkatkan suhu awal gelatinisasi pati talas banten. Takahashi dkk (2005) menyatakan bahwa selama proses HMT memungkinkan terbentuknya ikatan baru yang lebih kompleks antara amilosa pada bagian kristalin dan amilopektin pada bagian amorphous, sehingga menghasilkan formasi kristalin baru yang memiliki ikatan lebih kuat dan rapat. Peningkatan suhu awal gelatinisasi menunjukkan pati lebih resisten terhadap panas dan membutuhkan suhu yang lebih tinggi lagi untuk dapat mulai tergelatinisasi.

\section{- Viskositas Puncak}

Berdasarkan pada hasil analisis nilai viskositas puncak pati talas banten alami adalah $3899.5 \mathrm{cP}$ sedangkan nilai viskositas puncak pati talas banten termodifikasi HMT adalah $4845.5 \mathrm{cP}$ hingga $6002.5 \mathrm{cP}$. Hal ini menunjukkan bahwa perlakuan modifikasi HMT cenderung meningkatkan viskositas puncak pati talas banten namun perlakuan lama modifikasi HMT cenderung menurunkan viskositas puncak seiring dengan meningkatnya lama pemanasan.

Pati yang memiliki kemampuan penyerapan air yang tinggi akan mengalami pembengkakan yang tinggi pula yang berakibat pada tingginya viskositas puncak pasta. Pembengkakan granula pati yang berlebihan akan dikuti dengan peluruhan molekul amilosa dari dalam granula sebagai akibat ketidakmampuannya menahan tekanan. (Wulandari, 2010)

\section{- Viskositas Pasta Panas dan Viskositas Breakdown}

Parameter viskositas pasta panas dan breakdown terkait satu sama lain karena breakdown merupakan selisih antara viskositas puncak dengan viskositas pasta panas. Penurunan viskositas pasta panas umumnya diikuti dengan peningkatan breakdown. Namun demikian, pada kondisi tertentu penurunan viskositas pasta panas tidak selalu diiringi dengan peningkatan breakdown. Apabila viskositas pasta panas dan viskositas puncak menurun secara proporsional maka breakdown akan cenderung tetap. (Marta, 2011)

Berdasarkan pada hasil analisis nilai viskositas pasta panas pati talas banten alami adalah $1612.5 \mathrm{cP}$ sedangkan nilai viskositas puncak pati talas banten termodifikasi HMT adalah $2851.5 \mathrm{cP}$ hingga 3280.5.5 cP. Hal ini 
menunjukkan bahwa perlakuan modifikasi HMT cenderung dapat meningkatkan viskositas pasta panas namun sebaliknya perlakuan lama modifikasi HMT dapat menurunkan viskositas pasta panas seiring dengan meningkatnya lama pemanasan.

Viskositas Breakdown merupakan selisih antara viskositas puncak dengan viskositas pasta panas. Kecenderungan perubahan nilai viskositas breakdown yang terjadi pada pati talas banten termodifikasi HMT sangat kecil sehingga tidak berbeda nyata dengan viskositas breakdown pati talas banten alami. Berdasarkan pada hasil analisis nilai viskositas breakdown pati talas banten alami adalah $2287 \mathrm{cP}$ sedangkan nilai viskositas breakdown pati talas banten termodifikasi HMT adalah 1994 cP hingga 2722 cP. Hasil ini menunjukkan bahwa lama modifikasi HMT memberikan hasil yang beragam terhadap nilai viskositas breakdown pati talas banten termodifikasi HMT.

Penurunan viskositas breakdown diduga karena meningkatnya keteraturan matriks kristalin yang menurunkan kapasitas pembengkakan granula dan memperbaiki stabilitas pasta selama pemanasan (Hoover dkk,1993 dikutip Pukkahuta dkk,2008).

\section{- Viskositas Pasta Dingin dan Viskositas Setback}

Viskositas pasta dingin pati talas banten termodifikasi HMT cenderung mengalami peningkatan bila dibandingkan dengan viskositas pasta dingin pati talas banten alami. Perubahan viskositas pasta dingin yang terjadi antar perlakuan lama modifikasi HMT cenderung tidak stabil dan membentuk pola yang fluktuatif, namun demikian nilai viskositas pasta dingin pati termodifikasi HMT masih lebih tinggi bila dibandingkan dengan viskositas pasta dingin pati talas banten alami.

Berdasarkan pada hasil analisis nilai viskositaspasta dingin pati talas banten alami adalah $2374 \mathrm{cP}$ sedangkan nilai viskositas pasta dingin pati talas banten termodifikasi HMT adalah $4325 \mathrm{cP}$ hingga $5145.5 \mathrm{cP}$. Hasil tersebut menunjukkan pati talas banten termodifikasi HMT memiliki nilai viskositas pasta dingin yang cenderung tinggi. Nilai viskositas pasta dingin menunjukkan kemampuan pati untuk cepat mengalami retrogradasi. Semakin meningkat nilai viskositas pasta dingin, maka kecenderungan pati membentuk gel sangat mudah (Wulandari, 2010).

Setback atau perubahan viskositas selama pendinginan diperoleh dari selisih antara viskositas pasta dingin dengan viskositas pasta panas. Semakin tinggi nilai setback maka menunjukkan semakin tinggi pula kecenderungan untuk membentuk gel (meningkatkan viskositas) selama pendinginan. Tingginya nilai setback menandakan tingginya kecenderungan untuk terjadinya retrogradasi. (Marta, 2011)

Viskositas setback pati talas banten termodifikasi HMT cenderung mengalami peningkatan bila dibandingkan dengan viskositas setback pati talas banten alami. Perubahan viskositas setback yang terjadi antar perlakuan lama modifikasi HMT cenderung tidak stabil dan membentuk pola yang fluktuatif, namun demikian nilai viskositas setback pati termodifikasi HMT masih cenderung lebih tinggi bila dibandingkan dengan nilai viskositas setback pati talas banten alami.

Berdasarkan pada hasil analisis nilai viskositas setback pati talas banten alami adalah $761.5 \mathrm{cP}$ sedangkan nilai viskositas setback pati talas banten termodifikasi HMT adalah $1473.5 \mathrm{cP}$ hingga $1865 \mathrm{cP}$.

\section{Data Hasil Pengamatan Keseluruhan}

Perbandingan sifat fungsional dan sifat amilografi pati talas banten alami dan pati talas banten termodifikasi HMT hasil pengujian dan pati ubi jalar termodifikasi HMT yang sesuai untuk pembuatan produk bihun dapat dilihat pada Tabel 1 .

Tabel 1. Perbandingan Hasil Sifat Fungsional dan Sifat Amilografi Pati Talas Banten dengan Pati Ubi Jalar Termodifikasi HMT

\begin{tabular}{|c|c|c|c|}
\hline \multirow{2}{*}{ Kriteria Pengamatan } & \multicolumn{2}{|c|}{ Pati Talas Banten } & \multirow{2}{*}{$\begin{array}{c}\text { Pati Ubi Jalar } \\
\text { HMT }^{\mathrm{a}}\end{array}$} \\
\hline & Alami & HMT & \\
\hline Kapasitas Penyerapan Air (g/g) & 1.42 & 1.79 hingga 1.89 & - \\
\hline Swelling volume $(\mathrm{ml} / \mathrm{g})$ & 14.47 & 8.50 hingga 14.20 & - \\
\hline Kelarutan $(\%)$ & 6.65 & 6.70 hingga 18.20 & 10.9 \\
\hline Derajat Putih (\%) & 89.89 & 80.19 hingga 81.45 & - \\
\hline Freeze-Thaw Stability (\%) & 19.37 & 29.04 hingga 43.58 & - \\
\hline Suhu Awal Gelatinisasi $\left({ }^{\circ} \mathrm{C}\right)$ & 81.95 & 82.77 hingga 83.76 & - \\
\hline Viskositas Puncak (cP) & 3899.5 & 4845.5 hingga 6002.5 & 3109 \\
\hline Viskositas Pasta Panas (cP) & 1612.5 & 2851.5 hingga 3280.5 .5 & 3058 \\
\hline Viskositas Breakdown (cP) & 2287 & 1994 hingga 2722 & 51 \\
\hline Viskositas Pasta Dingin (cP) & 2374 & 4325 hingga 5145.5 & 5183 \\
\hline Viskositas Setback (cP) & 761.5 & 1473.5 hingga 1865 & 2125 \\
\hline
\end{tabular}

Sumber: ${ }^{\mathrm{a} C o l l a d o}$ dkk (2001)

Keterangan : - (tidak dilakukan) 


\section{Kesimpulan dan Saran}

\section{Kesimpulan}

Berdasarkan pada hasil penelitian dapat disimpulkan bahwa lama modifikasi HMT memberikan perubahan yang beragam terhadap sifat fungsional dan sifat amilografi pati termodifkasi HMT. Pati Talas Banten termodifikasi HMT mengalami peningkatan nilai kapasitas penyerapan air, penurunan nilai swelling volume, kecenderungan peningkatan freeze-thaw stability, kelarutan, suhu awal gelatinisasi, viskositas puncak, viskositas pasta panas, viskositas pasta dingin dan viskositas setback serta kecenderungan penurunan nilai derajat putih dan viskositas breakdown. Selain itu, modifikasi HMT telah mampu memperbaiki nilai kelarutan, viskositas pasta panas dan viskositas pasta.

\section{Saran}

Saran berdasarkan penelitian ini adalah diharapkan adanya penelitian lanjutan mengenai pemanfaatan pati talas banten termodifikasi HMT dan mengetahui kesesuaian sifat fungsional dan sifat amilografi pati termodifikasi HMT ketika diaplikasikan ke dalam pembuatan produk.

\section{Daftar Pustaka}

Balai Besar Pengkajian dan Pengembangan Teknologi Pertanian (BBP2TP). 2015. Teknologi Pengolahan Talas Beneng. Available at: http://bbp2tp.litbang.pertanian.go.id (diakses pada 20 April 2015)

Collado, L.S. dan H. Corke. 1999. Heat-moisture treatment Effects on Sweetpotato Starches Differing in Amylose Content. Food Chemistry 65: 339 - 346.

Collado, L.S., L.B. Mabesa, C.G. Oates dan H. Corke. 2001. Bihon-type of Noodles from Heat Moisture Treated Sweet Potato Starch. J. Food Sci. 66(4): 604-609.

Felicia. 2010. Penggunaan Pati Sagu Termodifikasi dengan Heat Moisture-Treatment (HMT) untuk Meningkatkan Kualitas Tekstur Bakso Daging Sapi. Skripsi Sarjana Ilmu dan Teknologi Pangan, Institut Pertanian Bogor.

Kadan, R.S., R.J. Bryant dan A.B. Pepperman. 2003. Functional Properties of Extruded Rice Flours. Journal of Food Science Vol. 68, Nr. 5.

Marta, H. 2011. Sifat Fungsional dan Reologi Tepung Jagung Nikstamal Serta Contoh Aplikasinya pada
Pembuatan Makanan Pendamping ASI. Sekolah Pasca Sarjana Institut Pertanian Bogor.

Ramadhan, Kurnia. 2009. Aplikasi Pati SaguTermodifikasi Heat Moisture Treatment Untuk Pembuatan Bihun Instan. Skripsi Sarjana Ilmu dan Teknologi Pangan, Institut Pertanian Bogor.

Singh S, Raina CS, Bawa AS, and Saxena DC. 2006. Effect of Heat-Moisture Treatment and Acid Modification of Rheological, Textural and Differential Scanning Calorimetry of Sweetpotato Starch. J of Food Sci 70 (6) :373-378

Sunarti, T.C., N. Richana., F. Kasim., Purwoko dan A. Budiyanto. 2007. Karakterisasi Sifat Fisiko Kimia Tepung dan Pati Jagung Varietas Unggul Nasional dan Sifat Penerimaannya terhadap Enzim dan Asam. Departemen Teknologi Industri Pertanian. Fakultas Teknologi Pertanian. IPB Bogor.

Syamsir E. 2012. Mempelajari Fenomena Perubahan Karakteristik Fisikokimia Tapioka karena Heatmoisture Treatment dan Model Kinetikanya. Sekolah Pasca Sarjana Institut Pertanian Bogor.

Takahashi S, Maningat CC, Seib PA. 1989. Acetylated and hidroxipropylatedwheat starch: paste and gel properties compared with modified maize andtapioca starches. Cereal Chem 66: 499-506.

Wahyuni, T. S. 2010. Pembuatan Dekstrin dari Pati Umbi Talas dengan Hidrolisis secara Enzimatis. Skripsi Sarjana Teknologi Pangan. Universitas Pembangunan Nasional "Veteran" Jawa Timur.

Wattanachant, S., S.K.S. Muhammad, D.M. Hashim, dan R.A. Rahman. 2002. Characterization of Hydroxypropylated Crosslinked Sago Starch as Compared to Commercial Modified Starches. Journals of Science and Technology 24 (3): 439450 .

Wulandari, D. 2010. Karakteristik Fisik Pati Sagu (Metroxylon sp) yang Dimodifikasi dengan Teknik Heat Moisture Treatment (HMT). Tesis. Sekolah Pascasarjana. Institut Pertanian Bogor. Bogor

Sunarti, T.C., N. Richana., F. Kasim., Purwoko dan A. Budiyanto. 2007. Karakterisasi Sifat Fisiko Kimia Tepung dan Pati Jagung Varietas Unggul Nasional dan Sifat Penerimaannya terhadap Enzim dan Asam. Departemen Teknologi Industri Pertanian. Fakultas Teknologi Pertanian. IPB Bogor.

Syamsir E. 2012. Mempelajari Fenomena Perubahan Karakteristik Fisikokimia Tapioka karena Heatmoisture Treatment dan Model Kinetikanya. Sekolah Pasca Sarjana Institut Pertanian Bogor.

Zavareze, E.D.R dan A.R.G. Dias. 2011. Impact of heatmoisture treatment and annealing in starches: A review. Carbohydrate Polymer 83: 317-328. 